\title{
School experience of the child and adolescent with visual impairment: family experience
}

\author{
Vivência escolar da criança e adolescente com deficiência visual: experiência da família \\ Vivencia escolar del niño y adolescente con discapacidad visual: experiencia de la familia
}

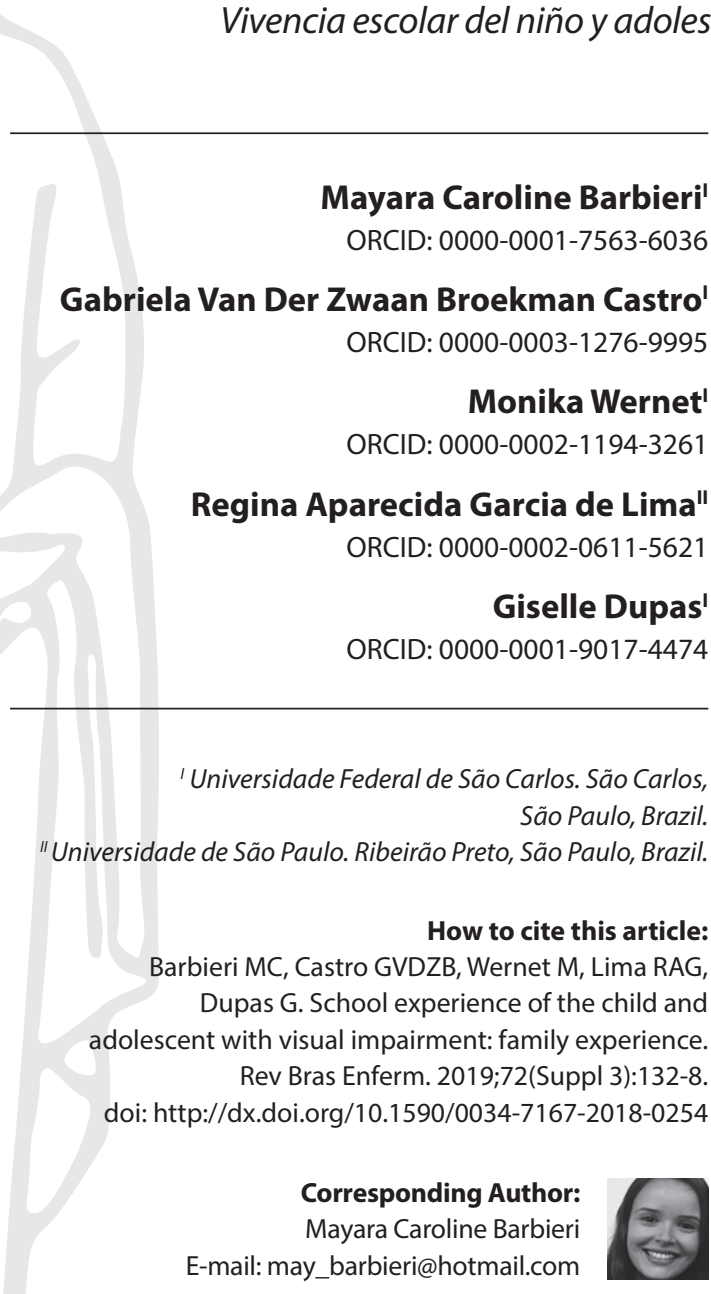

Submission: 04-30-2018 Approval: 07-18-2018

\begin{abstract}
Objective: to understand the experience of families about school experiences of children and adolescents with visual impairment. Method: a qualitative study developed through the Symbolic Interactionism and narrative research. Data were collected through a semistructured recorded interview, with eleven families of children/adolescents with visual impairment, totaling 40 participants. Results: two phenomena emerged: "exclusion context" and "impaired school performance". Prejudice experienced at school brings devastating consequences to the life of the visually impaired child/adolescent and his family. Isolation occurs, difficulty adapting to the support resource and deficits in school performance. Final considerations: production contributes to awakening professionals involved with the assistance of these people. Effective participation of health professionals in this area is required to develop actions with students, teachers and families, aimed at meeting the needs of learning and health promotion, inclusion, and respect for differences. Descriptors: Vision Disorders; School Health; Family Nursing; Child; Adolescent.
\end{abstract}

\section{RESUMO}

Objetivo: compreender a experiência de famílias sobre a vivência escolar de crianças e adolescentes com deficiência visual. Método: estudo qualitativo, desenvolvido através dos referenciais Interacionismo Simbólico e pesquisa de narrativa. A coleta de dados ocorreu por meio de entrevista semiestruturada gravada, com onze famílias de crianças/ adolescentes com deficiência visual, totalizando 40 participantes. Resultados: emergiram dois fenômenos: "contexto de exclusão"e "desempenho escolar prejudicado". O preconceito vivenciado na escola traz consequências devastadoras para a vida da criança/adolescente com deficiência visual e sua família. Ocorre isolamento, dificuldade de adaptação ao recurso de apoio e déficit no desempenho escolar. Considerações finais: a produção contribui para despertar profissionais envolvidos com assistência dessas pessoas. É necessária uma participação efetiva de profissionais de saúde neste espaço para que desenvolvam ações junto a alunos, professores e familiares, voltadas para atendimento às necessidades de aprendizagem e promoção da saúde, inclusão, e respeito às diferenças.

Descritores: Pessoas com Deficiência Visual; Saúde Escolar; Enfermagem Familiar; Criança; Adolescente.

\section{RESUMEN}

Objetivo: comprender la experiencia de las familias sobre la vivencia escolar de niños y adolescentes con discapacidad visual. Método: estudio cualitativo, desarrollado a través de los referenciales Interacionismo Simbólico e investigación de narrativa. La recolección de datos ocurrió por medio de una entrevista semiestructurada grabada, con once familias de niños/adolescentes con deficiencia visual, totalizando 40 participantes. Resultados: surgieron dos fenómenos: "contexto de exclusión" y "desempeño escolar perjudicado". El preconcepto vivido en la escuela trae consecuencias devastadoras para la vida del niño/adolescente con discapacidad visual y su familia. Ocurre aislamiento, dificultad de adaptación al recurso de apoyo y déficit en el desempeño escolar. Consideraciones finales: la producción contribuye a despertar a profesionales involucrados con la asistencia de esas personas. Es necesaria una participación efectiva de profesionales de salud en este espacio para que desarrollen acciones junto a alumnos, profesores y familiares, orientadas a atender las necesidades de aprendizaje y promoción de la salud, inclusión, y respeto a las diferencias. Descriptores: Personas con Daño Visual; Salud Escolar; Enfermería de la Família; Niño; Adolescente. 


\section{INTRODUCTION}

Visual impairment (VI) encompasses low vision and blindness, both of which limit the execution of daily activities, bringing repercussions to everyday life. Epidemiological data from the Brazilian Council of Ophthalmology (Conselho Brasileiro de Oftalmologia) show that around $5 \%$ to $10 \%$ of pre-school children already present some type of visual problem, such as refractive errors, being the main cause of $\mathrm{VI}$ in children in Brazil ${ }^{(1)}$. Thus, this condition is present in the school context and imposes to the professionals inserted in this environment the challenge of promoting learning that allow respectful respect and consideration to the differences of each human being ${ }^{(2)}$.

Among the national policies for child and adolescent care, the Ministry of Education adopts inclusive education for people with $\mathrm{VI}$, which presupposes the specialized educational service, aiming at the complementation of their education and no longer to the replacement of regular education ${ }^{(3)}$.

Moreover, there is the Health School Program (PSE - Programa Saúde na Escola) ${ }^{(4)}$, an intersectoral policy derived from the partnership between the Ministry of Health and the Ministry of Education, which aims to contribute to comprehensive training of students in the public school system with the development of actions, through the intersectoriality, for promotion, prevention and attention to health. Nursing has important attributions to collaborate with the school community, with potential to develop actions that promote autonomy, health and conviviality with the differences existing in this space ${ }^{(5)}$. In view of the above and in line with the importance of school in the development and social integration of the child, the question arises: how is it possible for the family to experience school inclusion of children and adolescents with VI from the perspective of Symbolic Interactionism?

\section{OBJECTIVE}

To understand the experience of families about school experiences of children and adolescents with visual impairment.

\section{METHOD}

\section{Ethical aspects}

The research from which this article is derived was approved by the Research Ethics Committee with Human Beings of the Universidade Federal de São Carlos. The guidelines contained in Resolution 466/2012 of the Brazilian Health Board (Conselho Nacional de Saúde) were respected ${ }^{(6)}$. Participating members were informed about the contents of the Free and Informed Consent Term (FICT), and those under eighteen years of the Assent Term (AT); and everyone signed them.

\section{Theoretical-methodological framework}

This study used the Symbolic Interactionism (SI) approach as a theoretical framework to give support to the development of the research and to help in understanding the phenomena that are involved in family dynamics and interaction, making possible the understanding of how people understand social objects and how such understanding affects behaviors and experiences ${ }^{(7)}$.
Participants were children and adolescents with VI (low vision) and their families, considering the concept of family proposed by Wright and Leahey, in which the family composition is defined by who its own members recognize to $b^{(8)}$.

\section{Type of study}

This is a descriptive research with a qualitative approach.

\section{Methodological procedures}

\section{Study setting}

The research was carried out in a city located in São Paulo countryside. The families were located based on data provided by the State Education Office of São Paulo State (Secretaria Estadual de Educação do Estado de São Paulo), which included the number of children and adolescents allocated to each school and the registration data, totaling 26 children and adolescents with VI. Only one private school age, and the other 25 were from the public school system. All schools were contacted in person, so we could explain the research and present the necessary documentation. Thus, the initial approximation with families was mediated by the principals and coordinators of schools.

\section{Data source}

All families of children and adolescents with VI enrolled in the primary and secondary school system were addressed. Having the ability to answer questions was the criterion of inclusion. We excluded children and/or adolescents with VI who presented other types of impairments or associated malformations. These criteria were analyzed by the researchers in the process of approximation with the potential participants, and the sampling was by convenience.

Of the 26 families surveyed, 14 refused to participate in the survey because of personal problems and lack of interest. Twelve families of 13 children and adolescents were interviewed, but one was excluded from the analysis because, during the interview, the family reported that the child had a diagnosis of microcephaly associated with $\mathrm{VI}$.

\section{Collection and organization of data}

Data were collected from November 2014 to July 2015 in São Paulo City under study. For data collection, genogram, ecomap and semi-structured interview were elaborated in a single meeting. The audio was recorded at the interviewees' homes or in a reserved room in the school environment, according to family preference. To identify the interview cut-offs, we used the relationship that the person interviewed presented in relation to the child or adolescent, called the index case (IC), followed by the sequential number with which the interview was performed. In cases involving more than one member with the same degree of kinship, these were identified with the family number followed by another number that will be in ascending order, representing from the older brother to the younger. Example: IC 5.1, IC 5.2, Mother 2, Brother 9. 


\section{Data analysis}

The data were elaborated according to the analytical processes inherent in narrative research in the holistic and thematic modality ${ }^{(9)}$. Narratives highlight the potential of the discourse in an interactive way, taking into account the affability of the relationships involved in the narrated context, thus giving the narrator opportunities for transformations between intrinsic and extrinsic aspects of their relationship with the world ${ }^{(10)}$. The choice of this approach was supported by its adequacy to the theoretical framework and by the understanding that, when narrating, (re)elaboration of social experience occurs, with selection of contents relevant to the phenomenon on which the narrative is developed ${ }^{(11)}$.

Initially, interviews were conducted and transcribed in their entirety; later, the material went through readings and re-readings focusing on the history as a whole for the establishment of its central nucleus. Next, new reiterative readings were made searching for contents and themes exposed in such narratives, when prominence of representative sections of the same occurred. At the end of the process, the narrative reconstruction was performed based on themes established through the interpretative process carried out in the process ${ }^{(9)}$. Thus, the categories of analysis emerged - "exclusion context" and "impaired school performance" - which are presented below.

\section{RESULTS}

Of the 40 participants in the 11 families, 25 were female and 15 were male. In relation to the degree of kinship were: 8 ICs, 9 mothers, 2 parents, 2 stepfathers, 10 brothers, 1 uncle, 4 aunts, 3 grandmothers and 1 work supervisor (included for being considered family member by participants). One of the families had two members with VI. We emphasize that, throughout the article, we approach the family perspective, which does not exclude children and adolescents with $\mathrm{VI}$, as they are also members of the family.

Among the ICs, 8 participated in the interview, one did not participate because they were in school activity and the other 3 because they did not feel comfortable interacting during the interview. Of the total number of children and adolescents, nine were males and three females; the age ranged from eight to seventeen years. Among the causes of low vision were retinopathy of prematurity, congenital cataract, toxoplasmosis, retinal displacement, ocular thrombosis and congenital luxation in the lens.

The analysis of the narratives made it possible to understand that school is effective as a social space frequented by children with $\mathrm{VI}$ and their families, being described as difficult to interact, especially because they feel the presence of prejudice and rejection. In order to face such context, the family mobilizes its members, in an attempt to minimize the fragility found in the reception of school institutions. The themes: "exclusion context" and "impaired school performance" reflect the family's perception about school experience of children and adolescents with VI.

\section{Exclusion context}

The family's perception is that the child with VI in school faces difficulties related to prejudice, by colleagues and teachers, both regarding their borderline visual situation and the interventional resource (glasses, adapted materials) that they use. Associated with this, they experience exclusion by classmates. Such an interaction context generates intense suffering, which extends to the family, which is sympathetic, especially through shared reports.

Children and adolescents understand that they are beaten, seek justifications for such actions and reflect on the need to submit to them. They commonly consider sharing with their schoolmates the situation of life through which they pass, with the intention of sensitizing them to a different attitude. However, it can be seen from the reports that social isolation is of a size that the act of talking, a resource that promotes understanding, seems to be practically absent and unfeasible.

[...] for me, as a mother, it was much harder! [...] [Mother gets emotional and cries] [...] it seemed that he was depressed, he cried a lot, he stayed in the room. [...] he was down, then he was away from school, so we realized he was not going to school because he was afraid, ashamed [...]. (Mother 1)

I wanted them [classmates] to talk to me, let them understand me more. Because it's bad they do not talk to me [...]. (IC 5.2)

Suffering is intense and promotes high levels of stress, so there is the plea to the family to be able to leave school. This action is seen by family members with great surprise and dissatisfaction, as they consider it unusual for a child to feel the desire not to go to school.

[...] He asked for a Christmas present "I wanted Mom to get me out of school!". Do you think a 10-year-old says that? (Mother 5)

[...] in school, it's very difficult, I cannot see much. When I go to ask a colleague for help, they do not like it, then I'Il tell the teacher, and the teacher tries to solve it, but it's no use. [...] Those days ago I did not want to go to school anymore, because I cried, I kept quiet in my corner, because they kept calling me a squinting, four-eyed, you know? And I did not like. [...] It's the whole room that's prejudiced with me. (IC 12)

In addition, biased attitudes hinder the process of incorporation, adaptation and use of assistive technologies necessary to the VI framework, such as glasses, magnifying glass, notebook and large print books, $6 \mathrm{~B}$ or $3 \mathrm{~B}$ pencils and the reading book to approximate the child's books. The description is that, when using the resources, such as confirming the disability and difference of the child and adolescent before the colleagues, causes feedback of prejudiced attitudes.

He lives in situations of prejudice in school, because he does not go with glasses, I'm sure they mock him [...] When he put on the glasses he was ashamed, said "I will not wear this!". So you realize that this is from school, from friends. He says he has a friend, but he does not! They even left, after he lost his vision, it was over! (Mother 8)

He does not use the magnifying glass [...] also does not use the board that puts the notebook for them to work and write with the book standing, and then they throw the notebook and this cannot ... the two do not like to use. (Mother 5)

I do not use it because others keep looking. (Cl 5.2) 
The feeling of being different from other colleagues is strong and gains a certain acceptance in the associations of friendship with another child and adolescent who also experience something common to them.

My friend from school is also visually impaired and in the third year he did not speak very well, you know? He was going to talk and we did not understand what he was saying ... I was teaching him and now he is speaking well. [...] He wears glasses, but he can see better than I can. (IC 5.2)

The experience of prejudiced attitudes is daily, generates wear and tear, and sometimes promotes violent acts (verbal or physical), meaning as a defense by the child with Vl.

One time a kid started teasing me, calling me squint, these things. Then I put the chair on his forehead, opened it close to the eyebrow! (IC 4)

[...] changing schools will be useless because the problem is in them [...] they curse me and I try to defend myself. The more I try to defend myself, the worse they speak. (IC 11)

Family members who have experienced a similar situation due to VI are pitied, above all by recovering their own experiences of exclusion and recovering the suffering inherent in them. They feel anger and sadness in recalling such facts.

It's hard, I did not want them to go through it because it's something that stays for the rest of their lives. I remember how I was left alone at school, I had no friends. When it came time to do double work, nobody wanted to do it with me. I want them to be people anywhere [...]. (Sister 5)

Social inclusion of the child is desired, and school is conceived by the family as a space in which this can occur and, in consequence, despite the 'harmfulness' of the environment, hopes that the child and the adolescent learn to deal with the fact. Nevertheless, moving children and adolescents to such an environment is difficult and challenging for the family.

It's harder to see her with no choice. It is. Because living at home is normal. It's complicated at school. (Sister 11)

\section{Impaired school performance}

Children and adolescents with VI present difficulties to perform school tasks, the grades are low, they are disapproved, that is, they perform poorly. In the perception of the family, this has a correlation with the interactional context, added to the incipient reception and support provided by the school. Nevertheless, they point out the articulation between school performance and quality of the relationship that the student with VI establishes with his teachers, as well as their interest in supporting him.

It is important to highlight that the family recognizes the insufficiencies of learning and has an interest in contributing to the transformation of this situation. In this sense, they question the approval and continuity in the series.

[...] he [IC] does not know how to read, does not know how to write, how does this creature go to another grade? Then the coordinator of the school told me that it was the law, that he had to pass him, that it was obligation [...]. (Grandmother 3)

[...] look, here is another test. [Mother shows tests with grades varying from zero to three] Do you think I'm going to let a child pass this year? No way. [...] he already arrives stressed and angry from school; he already drops off angry from the bus because he cannot do things there to teach him then is an inconvenience. (Mother 5)

Faced with the difficulties faced in school learning, students with $\mathrm{VI}$ end up demanding from their families support in school tasks, which is often not possible, either because of the unavailability of time or even because they do not have conditions due to their own situation of insufficient literacy.

[...] she is having a lot of difficulty in math, geography, Portuguese, history [...] I'll see if they fit my daughter, for the teacher to teach in my place, because there's no way I can teach. (Mother 7)

Learning, learning for real, she is not learning. [...] at school I cannot help her much, I think at school it was the worst part, they are approving her for no reason, unfortunately this is how it works. (Mother 9)

Participants also emphasize as limits: the fact that the expanded material (didactic material printed with major alphabetical font) guaranteed by law is not available or arrives well after the beginning of the academic semester; and the inefficiency of school and school teachers in accommodating the specific demands of children and adolescents. Nonetheless, they strive to meet needs, even if they need to get involved in a long-term, bureaucratic search process.

[...] they do not increase the material. [...] / said, "teacher, write bigger, I cannot read" He said, "I will do it" but it shouldn't be done. (IC 11)

[...] few notebooks are enlarged, books are not [...] for me to get these materials was too exhausting, it was very difficult, I had to go to many places. (Mother 8)

In the perception of the family, the relationship with many teachers is identified as limiting the inclusion of the child and the adolescent because they are not involved with the situation or even doubting the referred VI. Those who are sensitive and professionally attentive to the special needs of some children, cannot, in the middle of a room with many students, meet the content of the child or adolescent, generating repercussion in learning.

Some teachers do not know. They think I'm a normal student wearing glasses. [...] what I think is wrong from the direction is that they do not warn the new teachers, they say they will warn, but nobody warns. (IC 9)

\section{DISCUSSION}

Considering the results of this research, difficulties in relations with school was intense and recurrent in the daily life of the families of children and adolescents with VI. Prejudice and bullying were emphasized in this experiment. It is worth mentioning that Law 13,146 of July 6 , 2015 guarantees that every person with a disability has the right to equal opportunity and not to suffer any form of discrimination ${ }^{(12)}$. 
A study carried out in São Paulo countryside with 232 adolescents from $6^{\text {th }}$ to $9^{\text {th }}$ year investigated the bullying phenomenon and observed that most occurrences occur in the classroom through verbal manifestations, mainly in the form of nicknames. This phenomenon is a public health problem, because it is related to personality and violence disorders, and also to the educational area, as it causes difficulties in school performance and abandonment ${ }^{(13)}$.

It was possible to perceive, from the narratives, that children and adolescents with VI may be resistant to using the support resources. The fact that some students with $\mathrm{VI}$ refuse to receive the support service in the school environment is justified because they feel uncomfortable, different and dependent on normovisual colleagues $^{(14)}$.

SI explains this phenomenon through the concept of mind, developed from a problem that needs resolution ${ }^{(7)}$. Thus, with experiences of prejudice, children and adolescents with VI begin to give a new meaning to treatment resources and support materials. What was initially seen as a tool to improve the quality of life, by facilitating the performance of daily activities, becomes an object of differentiation and therefore end up establishing a conflicting relationship and resistance to their use.

The student's resistance to using the available support resources due to prejudice is a factor that should be highlighted and observed by teachers during class activities. Research reveals a direct association between undiagnosed visual disturbance and school performance and further reinforces that to enhance student performance, the necessary treatment and correction must occur ${ }^{(15)}$.

From the execution of the PSE, the nurse can act directly in the promotion and prevention of health, in the identification of the risks in school, as well as in the impact that actions such as bullying can cause in the formation and in the process of learning, health and quality of life of these students and to look for the factors related to this event ${ }^{(5)}$. Work of professionals, in the face of the effects of bullying is essential, as this can have consequences for adult life ${ }^{(16)}$.

These social actors have specific learning conditions that need to be supported, because being able to grasp what is taught can grant them an empowerment towards their colleagues. Not only the physical situation, but the cognitive one, perceived by him, makes him feel in an unfavorable situation.

In this study, conflicting relationships, lack of support and experiences of prejudice from colleagues and teachers, act directly on the student's school performance with VI. The feelings experienced when passing through prejudiced situations collaborate directly in school performance of the disabled child, besides causing deficits in the relationship with the family itself, colleagues and with teachers ${ }^{(17)}$.

Another study emphasizes that in the family environment, the potential for independence of the visually impaired child is superior to that of the school environment, where it suffers discrimination and prejudice. School and home have interference in human independence, thus, they need reorganization as well as their functionality vis-à-vis the visually impaired ${ }^{(18)}$.

The narratives point out that attitudes of exclusion and prejudice have provoked physical and/or verbal violence among people with $\mathrm{VI}$ and colleagues. A research that worked with twelve adolescents of a public school revealed that the violence is naturally faced by the students, justified by the frequency of the acts being increased, which entails the banalization of the phenomenon. The research indicates that violence in school occurs due to attitudes of prejudice, exclusion, disrespect and acts of physical aggression ${ }^{(19)}$.

Prevention and treatment actions for this phenomenon must be carried out with interdisciplinary and intersectorial works to allow students to change the perception of school, becoming a safe environment and with a view to the conservation of mental health ${ }^{(16)}$.

$\mathrm{SI}$ explains social interaction as the central concept of the theory ${ }^{(7)}$. This phenomenon is presented in the investigation by understanding that the person attributes meaning to the interactions established with the other and with himself and, from this, acts based on his understanding. Thus, from the conflicting and humiliating interactions with the colleagues, children and adolescents with $\mathrm{VI}$ signify such attitudes and establish a resistance position to attend school, an attitude that can be understood as protective of oneself, as well as a struggle for recognition.

Parents and teachers feel dissatisfied with inclusive education; a conflict in the relationship between family and school is evident, leaving the focus of discussion aside from inclusion in regular schools. For this relationship to be successful, it is necessary to invest in the dialogue between these subjects and in the common objective of enabling the school environment to become for people with disabilities a space of knowledge and development ${ }^{(17)}$. The importance of affectivity and pedagogical practices focused on diversity as the drivers of the teaching-learning process and development of the visually impaired child is elucidated ${ }^{(20)}$.

The weaknesses found in school and government support network are intense. Thus, the family mobilizes to acquire resources adapted for the teaching of children and adolescents with VI. Research carried out in Australia, with 14 students with $\mathrm{Vl}$, five parents and four teachers, who aimed to observe the impact of the support services provided to students with VI, such as access to assistive technology and an expanded curriculum, affirm that these strategies are essential for solving academic problems. Moreover, students presented better school performance and social relationships with improved confidence, improved communication and body language ${ }^{(14)}$.

Support and provision of expanded material is essential for people with $\mathrm{VI}$, because in the absence of such resources, they do not have the same learning opportunities. Legislation supports inclusive education by stating that it is the duty of vocational schools and institutions to provide, if necessary, specialized support to meet the needs of the disabled and to adapt to instructional resources such as teaching materials, equipment and the curriculum itself. The same decree deals with the qualification of human resources and the adequacy of the physical structure for these people ${ }^{(3)}$.

Among the weaknesses in the support network for families and children with $\mathrm{VI}$, we can still find educators without the preparation for inclusive education ${ }^{(21)}$. Teachers are key to the child's learning. UNICEF recommends that these professionals know in fact what it is to promote inclusive education and to take on such responsibilities to teach all children. However, they still reinforce that the teacher alone does not develop the full potential of inclusion 
of the children and that, for this, one must rely on the support of the family ${ }^{(21-22)}$. It is emphasized that the inclusion process is not only due to the educators' actions, these need government support to work with students with disabilities, as well as public policies feasible within the Brazilian reality.

\section{Study limitations}

One of the limitations of our research was the focus of the study focusing only on giving voice to the experience of the family and children with $\mathrm{VI}$, excluding the perception of teachers, managers of educational institutions and policy makers regarding school inclusion in the context of VI. Thus, new studies with an extended approach to these subjects should be performed so that we can cover the perception of the situation and envisage new paths towards the citizenship of children and adolescents with VI.

\section{Contributions to Health and Public Policy}

This production contributes to the awakening of those involved with care for the child and adolescent with VI in schools. Dialogical actions are recommended among the social subjects involved with $\mathrm{VI}$, with a view to densifying discussions aimed at guaranteeing what is right of the disabled person and his family, in addition to approaching the promotion of comprehensiveness in health, with consequences for the inclusion and life of these people.

There is evidence of the need for nurses to work in school and also establish partnerships with the families of children/adolescents with VI in the Primary Care Network, aiming at interlocution between health units and schools, promoting child development.

\section{FINAL CONSIDERATIONS}

It is understood the experience of families about school experience of children and adolescents with VI. School constitutes one of the first spaces of socialization after the family nucleus, in which children and adolescents will develop their potential of learning and interaction with colleagues and teachers. For VI students in the study city, this process is often flawed, difficult and full of traumas, especially in terms of exclusion, rights, selfesteem and learning. The school environment is recognized by the family as necessary, but also as source of suffering.

In this sense, the insertion of the nurse in schools would contribute to the work of promoting health with the students, teachers and family. Working with the concept of health, in addition to the absence of disease and bringing to these spaces the prevention of prejudiced attitudes, the appreciation of respect and individuality of each individual through critical and caring reflexivity could be a path.

Family as a whole realizes that school insertion of the visually impaired is ineffective, and seeks to solve questions intrinsic to the experience in school. Nevertheless, actions taken by the family go beyond what they can establish. It is noted the need to (re) elaborate this social experience, and professional actors as interlocutors between family and larger institutions.

\section{FUNDING}

This research was funded by the Research Support Foundation of São Paulo State (FAPESP - Fundação de Amparo à Pesquisa do Estado de São Paulo).

\section{REFERENCES}

1. Presidência da República (BR). Coordenadoria Nacional para Integração da Pessoa Portadora de Deficiência. Acessibilidade [Internet]. Brasília: Secretaria Especial dos Direitos Humanos; 2008 [cited 2017 Jun 16]. Available from: https://www2.senado.leg.br/bdsf/bitstream/ handle/id/43/Livro\%20-\%20Acessibilidade.pdf?sequence $=5$

2. Petrucci GW, Borsa JC, Koller SH. Family and school in the socioemotional development in childhood. Temas Psicol. 2016;24(2):403-13. doi: 10.9788/TP2016.2-01Pt

3. Presidência da República (BR). Decreto n 7611, de 17 de novembro de 2011 (BR). Dispõe sobre a educação especial, o atendimento educacional especializado e dá outras providências [Internet]. Diário Oficial da União, Brasília, 18 nov. 2011 [cited 2017 Jun 16]. Available from: http://www.planalto.gov.br/ccivil_03/_ato2011-2014/2011/decreto/d7611.htm

4. Sousa MC, Esperidião MA, Medina MG. Intersectorality in the 'Health in Schools' Program: an evaluation of the political-management process and working practices. Ciênc Saúde Colet. 2017;22(6):1781-90. doi: 10.1590/1413-81232017226.24262016

5. Silva MAI, Monteiro EMLM, Braga IF, Ferriani MGBC, Pereira B, Oliveira WA. Antibullying interventions developed by nurses: integrative review. Enferm Glob. 2017;16(48):563-76. doi: 10.6018/eglobal.16.4.267971

6. Presidência da República (BR). Resolução n 466, de 12 de dezembro de 2012 (BR). Aprova normas regulamentadoras de pesquisas envolvendo seres humanos [Internet]. Diário Oficial da União, Brasília, 12 dez. 2012 [cited 2017 Jun 16]. Available from: http://bvsms.saude. gov.br/bvs/saudelegis/cns/2013/res0466_12_12_2012.html

7. Charon JM. Symbolic interactionism: an introduction an interpretation, an integration. 10th ed. New Jersey: Prentice Hall; 2010.

8. Wright LM, Leahey M. Enfermeira e famílias: guia para avaliação e intervenção na família. 5a ed. São Paulo: Roca; 2012.

9. Lieblich A, Tuval-Mashiach R, Zilber T. Narrative research: reading, analysis and interpretation. Newbury Park: Sage; 1998.

10. Damasceno NFP, Malvezzi E, Sales CM, Sales A. Narratives as alternative in health research. Interface (Botucatu). 2018;22(64):133-40. doi: $10.1590 / 1807-57622016.0815$

11. Castellanos MEP. The narrative in qualitative research in health. Ciênc Saúde Colet. 2014;19(4):1065-76. doi: 


\section{$10.1590 / 1413-81232014194.12052013$}

12. Presidência da República (BR). Lei no 13.146, de 6 de julho de 2015 (BR). Institui a Lei Brasileira de Inclusão da Pessoa com Deficiência (Estatuto da Pessoa com Deficiência). Diário Oficial da União, Brasília, 7 jul. 2015 [cited 2017 Jun 16]. Available from: http://www.planalto. gov.br/ccivil_03/_ato2015-2018/2015/lei/l13146.htm

13. Sampaio JMC, Gerolim FR, Mello FCM, Mariano AC, Silva MAI. Bullying at school: analysis of conflict relations between adolescents. Rev Enferm UFPE. 2015;9(4):7264-71. doi: 10.5205/reuol.7275-62744-1-SM.0904201511

14. Datta P, Palmer C. Insights into the support services for students with vision impairment. Australas J Spec Educ. 2015;39(2):143-58. doi: https://doi.org/10.1017/jse.2015.8

15. Silva CMF, Almeida DR, Bernardes RR, Bazzano FCO, Mesquita Filho M, Magalhães CHT, et al. School performance: visual acuity interference. Rev Bras Oftalmol. 2013;72(3):168-71. doi: 10.1590/S0034-72802013000300005

16. Sampaio JMC, Santos GV, Oliveira WA, Silva JL, Medeiros M, Silva MAl. Emotions of students involved in cases of bullying. Texto Contexto Enferm. 2015;24(2):344-52. doi: 10.1590/0104-07072015003430013

17. Tónus D, Wagner LC. Inclusão em Escolas Regulares: percepção de pais e professores de crianças e adolescentes com deficiência. Ciênc Mov. 2013;XV(31):33-45. doi: 10.15602/1983-9480/cmedh.v15n31p33-45

18. Pintanel AC, Gomes GC, Xavier DM, Vaz MRC, Silva MRS. Influência ambiental para a (in)dependência da criança cega: perspectiva da família. Aquichan. 2016;16(1):94-103. doi: 10.5294/aqui.2016.16.1.10

19. Brandão Neto W, Silva ARS, Almeida Filho AJ, Lima LS, Aquino JM, Monteiro EMLM. Educational intervention on violence with adolescents: possibility for nursing in school context. Esc Anna Nery. 2014;18(2):195-201. doi: 10.5935/1414-8145.20140028

20. Ribeiro LOM. A inclusão do aluno com deficiência visual em contexto escolar: afeto e práticas pedagógicas. Rev Educ Artes Incl. 2017;13(1):8-32. doi: 10.5965/1984317813012017008

21. Sociedade Brasileira de Pediatria (SBP). Departamento Científico de Adolescência. Atualização sobre inclusão de Crianças e Adolescentes com Deficiência [Internet]. Rio de Janeiro: SBP; 2017 [cited 2018 Jan 16]. Available from: http://primeirainfancia.org.br/wp-content/ uploads/2017/05/Atualizao-sobre-Incluso-de-Crianas-e-Adolescentes-com-Deficincia.pdf

22. United Nations Children's Fund (UNICEF). Situação mundial na infância 2013: crianças com deficiência [Internet]. New York: UNICEF; 2013 [cited 2015 Feb 04]. Available from: http://www.crianca.mppr.mp.br/arquivos/File/publi/unicef_sowc/sit_mund_inf_2013_deficiencia.pdf 